\title{
Modeling of the Drying Kinetics of Two Extreme Parts of the Pulp of Gamboma Yam (Dioscorea cayenensis): Yellow Part (Head) and White Part (Tail)
}

\author{
Reyes H. Gampoula1,2*, Michel. G. Dzondo1,2,3,4, Arnaud W. G. Tamba Sompila1,2,4, \\ Nadia P. G. Pambou-Tobi1,2,4, Jacques E. Moussounga1,2,4, Philippe Diakabana, ${ }^{1,3,5}$, Roniche Nguie ${ }^{1,3}$ \\ ${ }^{1}$ Institut National de Recherche en Sciences de l'Ingénieur, Innovation et Technologie, cité scientifique, route de l'auberge de \\ Gascogne, Brazzaville, Congo \\ ${ }^{2}$ Ecole Nationale Supérieure Polytechnique (ENSP), Université Marien NGOUABI (UMNG), Brazzaville, Congo \\ ${ }^{3}$ EPRAN-Congo, Pôle d'Excellence en Alimentation et Nutrition, Faculté des Sciences et Techniques, Université Marien \\ NGOUABI, Brazzaville, Congo \\ ${ }^{4}$ Laboratoire d'Ingénierie Moléculaire et Sensorielles des Aliments, ENSP-UMNG, Brazzaville, Congo \\ ${ }^{5}$ Ecole Supérieure de Technologie des Cataractes, Brazzaville, Congo \\ Email: *reyes_herdenn@gmail.com
}

How to cite this paper: Gampoula, R.H., Dzondo, M.G., Sompila, A.W.G.T., Pambou-Tobi, N.P.G., Moussounga, J.E., Diakabana, P. and Nguie, R. (2021) Modeling of the Drying Kinetics of Two Extreme Parts of the Pulp of Gamboma Yam (Dioscorea cayenensis): Yellow Part (Head) and White Part (Tail). Open Journal of Applied Sciences, 11, 1218-1229.

https://doi.org/10.4236/ojapps.2021.1111092

Received: August 27, 2021

Accepted: November 19, 2021

Published: November 22, 2021

Copyright $\odot 2021$ by author(s) and Scientific Research Publishing Inc. This work is licensed under the Creative Commons Attribution-NonCommercial International License (CC BY-NC 4.0). http://creativecommons.org/licenses/by-nc/4.0/ cC) (7) (9) Open Access

\begin{abstract}
The study on the modelling of the drying kinetics of two extreme parts of the Gamboma yam pulp, the yellow part (head) and the white part (tail), was carried out to evaluate the behaviour of these two parts during drying. This evaluation was carried out in the oven at $70^{\circ} \mathrm{C}$ and in the microwave at 280 $\mathrm{W}$. The main aim of this work was to study experimentally while modelling the drying kinetics of the food and at the same time to evaluate the influence of temperature on two parts (head and tail) of the Gamboma yam. The effect of temperature on the food revealed the following results: a progressive decrease of the water content during the drying process in both the oven and the microwave. This experiment showed that during the drying of the two parts in the oven and in the microwave, the loss in mass evolves from the tail (white part) to the head (yellow part), because the white part is the youngest in terms of formation and the head, the oldest part in terms of formation. In the microwave and at $280 \mathrm{~W}$, the drying of the yam is faster than in the oven at $70^{\circ} \mathrm{C}$. During the modelling, four different mathematical drying models were used, namely Newton's, Page's, Henderson and Pabis' and finally Midili's, to assess the goodness of fit on the drying of the product while comparing their respective parameters $\mathrm{R}^{2}, \chi^{2}$ and RMSE. The comparison of the statistical parameters led to the selection of the Midili model as the one with better good-
\end{abstract}


ness of fit and better drying characteristics so as to obtain more expressive drying curves in contrast to other models.

\section{Keywords}

Dioscorea cayenensis, Modeling, Drying, Water Content

\section{Introduction}

Africa is one of the major producers of tuberous roots [1]. A large quantity of these products rot after harvest, which causes enormous post-harvest losses. Yam tubers are rich in starch and are part of the diet of many families in West and Central Africa [2]. Known as one of the oldest food preservation operations, drying reduces water activity. It is therefore a thermal separation operation which consists in eliminating by partial or total evaporation of the water contained in the food [3] [4]. It is a question of simultaneous transfers of heat, of mass between the product to be dried and the surrounding air.

The first in Africa to carry out the drying of Yam tubers is the Nigerians precisely in the south-western part, in the Yoruba countries. This technique then spread to Benin and Togo initially in response to demand from the Nigerian market [5]. These chips, which are obtained after pre-cooking and sun-drying the peeled tubers [6] [7], limit post-harvest losses and extend the period of product availability, thus strengthening food security [8]. Drying only takes place correctly during periods of low relative humidity, which allows rapid drying, under the conditions required to obtain quality chips [9].

Sun drying is commonly used in Africa, but its impact on the finished product can be unpleasant [10]. This is how the use of controlled atmosphere devices can be an alternative for preserving the quality of dried products.

The drying process follows an evolution which depends on time and speed, which is called drying kinetics.

Drying kinetics is a phenomenon that arises from the interaction of heat and mass transfers at the interface between the product, air and transfers within the same product [11].

This phenomenon makes it possible to evaluate the drying behavior of a product by determining the relationship between drying air speed, temperature, humidity and relative mass in terms of time. We obtain an equation which makes it possible to describe two characteristic curves [12].

This work aims to study the influence of different drying methods (oven and microwave) on the drying kinetics of two yellow and white parts of the yam and to understand the process of its water loss.

\section{Material and Method}

\subsection{Harvesting and Processing of Samples}

The plant material consists of yams (Dioscorea cayenensis) purchased at the 
Lycée Thomas Sankara market in the north of Brazzaville.

After receiving the raw material, the yams were cleaned, weighed, washed with water and peeled. After peeling the two parts (head and tail) were separated and weighed. The study was carried out on both ends of the yam pulp, namely the head (yellow part) and tail (white part).

\subsection{Drying Kinetics and Modeling}

The samples were dried in the Universal Microsil India, model OVS-3 oven brand at $70^{\circ} \mathrm{C}$, while we have worked with a power of $280 \mathrm{~W}$ in the Whirpool, EASY trunk, MO 201 microwave brand with two cooking levels.

The samples were weighed at regular intervals of $2 \mathrm{~min}$ for those in the oven and in the microwave from a branded precision balance (Ishida Japan) with an accuracy of $\pm 0.001 \mathrm{~g}$. The samples were dehydrated until the difference between the two consecutive readings was negligible or until it was constant. The initial water content of the two parts (white and yellow) was $78.02 \%$ (w.b).

The progress of the drying of the yellow part and the white part of the yam pulp revealed the variations in the dry base water content.

They are given according to the following formula:

Dry base water content: $X=\frac{m-M S}{M S}$ [13].

With:

$X$ : dry base water content ( $\mathrm{kg}$ of water $/ \mathrm{kg}$ of dry matter)

$m$ : mass of the product

DM: mass of dry matter ( $\mathrm{DM}=$ total starting mass - mass of starting water (calculated from the water content in wet basis).

The dry base water content also allowed us to determine the rate of drying over time according to the formula:

Drying speed: $-\frac{\mathrm{d} X}{\mathrm{~d} t}=\frac{X(t+\Delta t)-X(t)}{\Delta t}$

With: $-\mathrm{d} X / \mathrm{d} t$. drying speed in $\mathrm{kg}$ of water/ $\mathrm{kg}$ of $\mathrm{DM} / \mathrm{sec}$

$X$ : dry base water content ( $\mathrm{kg}$ of water $/ \mathrm{kg}$ of dry matter)

$\Delta t$. time difference in seconds.

Thus, three drying curves were obtained: the curve of the variation of the mass as in terms of time, the curve of the variation of the content in terms of time and the curve of the variation of the speed in terms of time.

\subsection{Modeling of Drying Kinetics}

Numerous studies have effectively used mathematical modeling for the analysis of drying of various foods [14].

For the modeling of the drying kinetics, we used the Origin Pro 8 software which allowed us to determine the $\mathrm{R}^{2}$ (coefficient allowing to predict the best equation which describes the drying curves), the reduced chi-square $\left(\chi^{2}\right)$ and the square root of the mean squared error (RMSE). Chi-square, coefficient of deter- 
mination $\mathrm{R}^{2}$, and RMSE are statistical parameters used to determine the quality of the model fit. The RMSE and the $\chi^{2}$ are calculated by the following equations:

$$
\begin{gathered}
\mathrm{R}^{2}=\frac{\sum_{i=1}^{n}\left(M_{R i}-M_{R p r e, i}\right)^{2}}{\sqrt{\left[\sum_{i=1}^{n}\left(M_{R i}-M_{R p r e, i}\right)^{2}\right] \times\left[\sum_{i=1}^{n}\left(M_{R i}-M_{\text {Rexp }, i}\right)^{2}\right]}} \\
\chi^{2}=\frac{\sum_{i=1}^{N}\left(M_{\text {Rexp }}(i)-M_{R p r e}(i)\right)^{2}}{N-n} \\
\text { RMSE }=\sqrt{\frac{1}{N} \times \sum_{i=1}^{N}\left(M_{\text {Rexp }(i)}-M_{\text {Rpre(i) }}\right)^{2}}
\end{gathered}
$$

With $M_{\text {Rexp }}(i)$ the ith experimental reduced water content, $M_{\text {Rpre }}(i)$ the ith predicted reduced water content, $N$ the number of experimental points and $n$ the number of constants of the model studied

The data used for the modeling with the Origin Pro 8 software was obtained from the reduced water content calculate as follows:

Reduced water content: $X^{*}=\frac{X}{X_{\text {initiale }}}$ [17]

With $X^{*}$ : The reduced content,

$X$ : dry base water content ( $\mathrm{kg}$ of water $/ \mathrm{kg}$ of dry matter) at a given time $t$,

$X_{\text {initiale: }}$ The initial water content of the product.

The following Table 1 gives the equations of the four models that we used:

The choice of the best model is based on the highest $\mathrm{R}^{2}, \chi^{2}$ and the lowest RMSE [18] [19].

\subsection{Statistical Analyses}

The data were analyzed by the Origin Pro 8 software (The Ultimate Software for Graphing \& Analysis, USA) by the nonlinear regression method of the Levenberg-Marquardt algorithm. The values of Coefficient of determination $\left(\mathrm{R}^{2}\right)$, reduced chi-squared $\left(\chi^{2}\right)$ and the mean square error (RMSE) were calculated to judge the predicted values relative to the experimental ones.

\section{Results and Discussion}

\subsection{Drying Kinetics}

The drying characteristic curves shown in Figures 1(a)-(c) were derived from the weight loss versus drying time of Gamboma yam.

These curves correspond to those obtained in the oven at $70^{\circ} \mathrm{C}$ and in the microwave at $280 \mathrm{~W}$.

\section{Drying Kinetics of $D$. cayenensis Pulp in an Oven at $70^{\circ} \mathrm{C}$}

The moisture content obtained shows that the number and duration of the phases changed according to the drying temperature of the yam. The heating phase does not appear on the drying characteristic of the curves showing the yellow and white part as shown by Beye, N.F et al., [20]. 
Table 1. Models used to model the drying of samples.

\begin{tabular}{ccc}
\hline Models & Equations & References \\
\hline Newton & $X^{*}=\exp (-k t)$ & Ayensu (1997) \\
Page & $X^{*}=\exp \left(-k t^{n}\right)$ & Ayensu (1997) \\
Henderson et Pabis & $X^{*}=a \times \exp (-k t)$ & Westerman et al., (1973) \\
Midilli & $X^{*}=\mathrm{a} \times \exp \left(-k t^{n}\right)+b \times t$ & Midilli et al., (2002) \\
\hline
\end{tabular}

$a, b, c$, coefficients and $n$, specific exponent of each drying equation; $k$ specific coefficients of each drying equation, $t$ is the drying time.

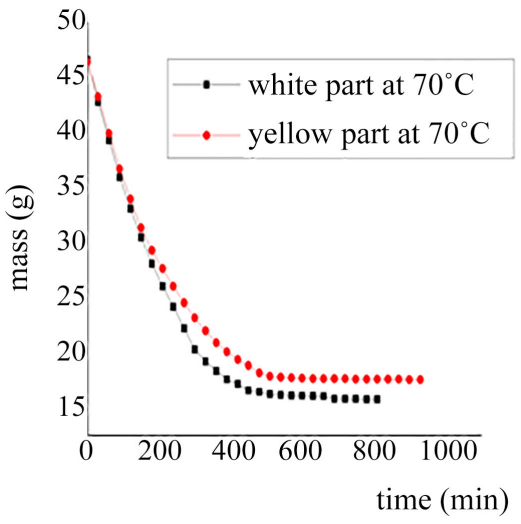

(a)

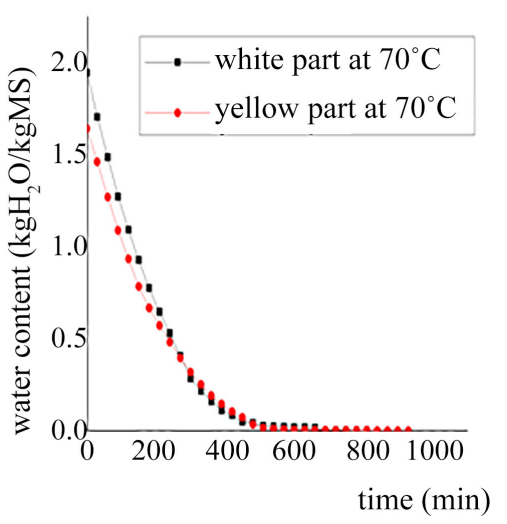

(b)

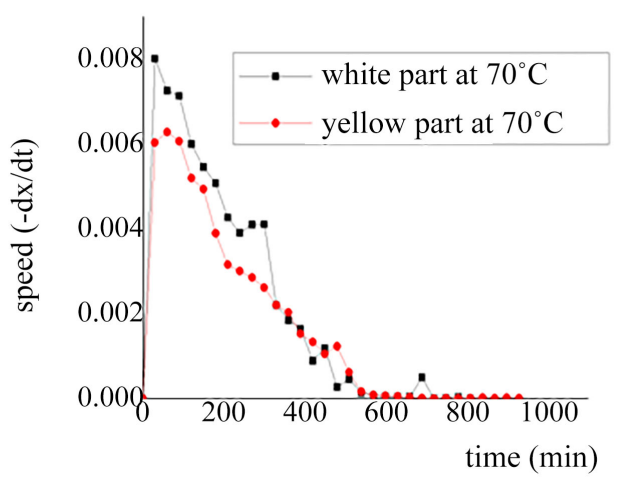

(c)

Figure 1. (a) Variation in the mass of the two parts (yellow and white) of Gamboma's Yam; (b) Variation in the water content of the two parts (yellow and white) of Gamboma's Yam; (c) Variation in the drying speed of the two parts (yellow and white) of Gamboma Yam.

Furthermore, a significant variation is observed in the evolution of the water content of both parts (head and tail) in the oven at $70^{\circ} \mathrm{C}$ (Figures 1 (a)-(c)). The white part dries faster than the yellow part. One explanation for this difference could be that: drying only takes place during the period of falling water content. This shows that diffusion is the dominant physical mechanism governing the movement of moisture in the samples [21]. Similar results were obtained by Rosello et al. [22] for green beans and Gupta et al. [23] for red pepper. It is obvious that the age of the yellow part has a significant impact on its drying curves. 
The curves in Figure 1(a) and Figure 1(b) have a classic dehydration pattern for water-rich plant products. They show two parts of the phenomenon:

- a period of optimum regime (between 0 and 400 minutes);

- a slow deceleration during which the mass becomes stable.

The mass at $70^{\circ} \mathrm{C}$ is $15 \mathrm{~g}$.

As the white part of the yam (tail) dries faster at $\left(70^{\circ} \mathrm{C}\right)$, this resulted in a decrease in time compared to the yellow part. The drying process occurred during the drop rate period in which the $70^{\circ} \mathrm{C}$ oven temperature led to a reduction in humidity levels to a greater extent which can be correlated with higher temperatures causing more transfer of moisture heat and mass [24].

The study of mass and heat transfer during the drying of starch products shows that these transfer phenomena also depend on the slice thickness and the water content of the product [25].

By following the shape of the curve of the yellow part (head), we notice that the drying time is longer than that of the white part.

The times taken by the yellow and white parts of the Gamboma Yam vary from 0 to $15.83 \mathrm{~h}$ for the yellow part against $13.3 \mathrm{~h}$ for the white part (Table 2). The difference is 2.53 hours.

The analysis of the variation in the water content of these two curves shows a similar appearance (Figure 1(b)), but this variation is faster in the white part than in the yellow part.

We also notice that the two speed curves (Figure 1(c)), reveal that the white part (tail) of the pulp of $D$. cayenensis has a higher drying speed than that of the yellow part (head):

\subsection{Pulp Drying Kinetics (Yellow and White) Corresponding to the Head and Tail of $D$. cayenensis in the Microwave}

The reduced moisture content versus time curves for microwave drying of the yellow and white parts of Gamboma yam at $280 \mathrm{~W}$ power are presented in Figures 2(a)-(c). As the microwave power is applied to both parts (yellow and white), it increases, and the time required to reach the final moisture content of $11 \% \mathrm{~kg}$ $\left[\mathrm{H}_{2} \mathrm{O}\right] \mathrm{kg}^{-1}$ dry matter decreases. The increase in microwave power therefore logically leads to a reduction in drying time. The same effects of microwave power were observed by Soyal [26] for parsley, Wang and Xi [27] for carrot slices and Gögüs and Maskan [28] for olive pulp.

Figures 2(a)-(c) below show the drying kinetics of yam pulp in the microwave:

By analyzing these figures, we notice the shape of the two curves. In Figure 2(a) and Figure 2(b), there is a similar decreasing pace. This similarity has been observed when drying Gamboma yam pulp in an oven [20]. On the other hand, when it comes to drying with the microwave, drying is faster because it is done in less time. The loss of free water becomes constant after 10 minutes of drying, but the white part always dries faster than the yellow part. 
Table 2. Drying time (h) of the yellow and white part of Gamboma yam in an oven at $70^{\circ} \mathrm{C}$.

\begin{tabular}{lcc}
\hline & Time $(\mathrm{h})$ & Temperature $\left({ }^{\circ} \mathrm{C}\right)$ \\
\hline Yellow part of the yam & 15.83 & 70 \\
White part of the yam & 13.3 & \\
\hline
\end{tabular}

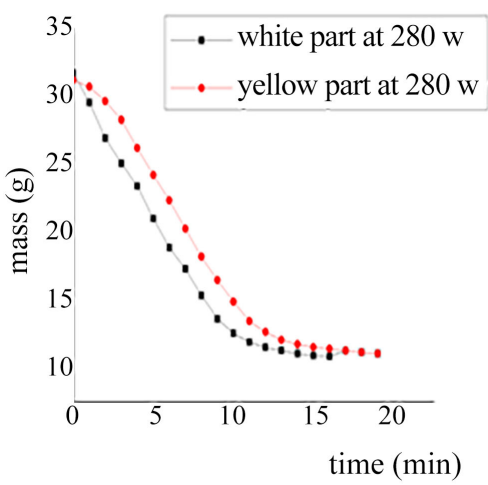

(a)

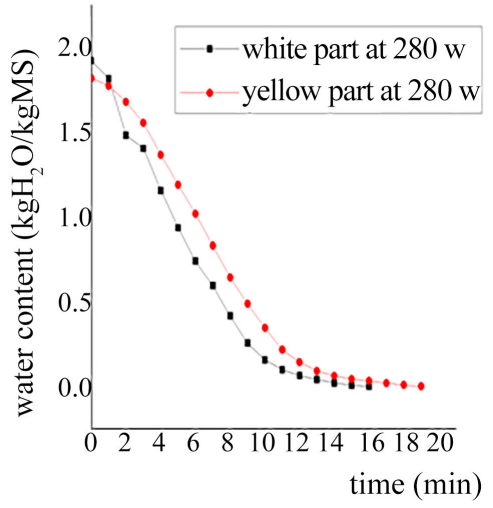

(b)

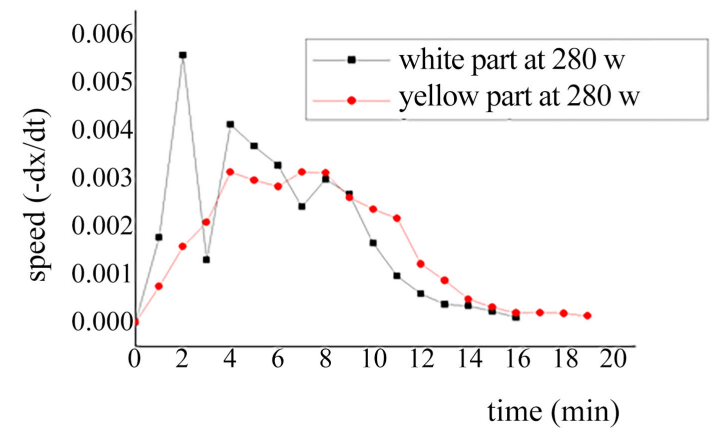

(c)

Figure 2. (a) Variation in the mass of the two parts (yellow and white) of Gamboma's Yam; (b) Variation in the water content of the two parts (yellow and white) of Gamboma's Yam; (c) Variation in the drying speed of the two parts (yellow and white) of Gamboma Yam.

It is well illustrated in Figure 2(b) where we can clearly see this variation. The water content varies faster during the $10 \mathrm{~min}$ and stabilizes around $12 \mathrm{~min}$.

In Figure 2(b), the water content of both yellow and white parts of Gamboma's Yam decreases faster at the start of drying between $0-10 \mathrm{~min}$, which leads to say that when storing yams, drying begins from the tail (white part) to the head (yellow part).

Figure 2(c) above illustrates this phenomenon well. In this figure, the drying speed of the white part remains greater than that of the yellow part. Crusting, decreased diffusivity of water during drying, and diffusion of water into the product that occurs during drying may explain the decrease in drying rate [29].

Or the drying of the different parts of Gamboma's Yam (Dioscorea cayenensis), we notice that the drying goes from the tail (white part) to the head (yellow 
part), given that the drying speed of the yellow part is weaker than that of the white part. These results are similar to those presented by Falade et al. [29] because according to them, the water content decreases by about 30\% DM from the end of the tuber towards its stem and from the axis towards the outer surface of the tubers.

In Table 3, we can see the time difference between these two parts.

\section{Modeling of Drying Kinetics}

The statistical parameters to assess fit quality were the coefficient of determination $\left(\mathrm{R}^{2}\right)$, reduced chi-square $\left(\chi^{2}\right)$, and the mean square error (RMSE) shown in Table 4 . The highest values of $\mathrm{R}^{2}$ and the lowest $\chi^{2}$ and the RMSE values were the criteria for selecting the best fit of the model [18] [19].

The results of this table IV show that, for the two parts of Dioscorea cayenensis dried in an oven, these values vary respectively from 0.98816 to 0.99849 , from $1.41281 \times 10^{-4}$ to 0.001 and from 0.01189 to 0.03167 (yellow part) and from 0.98527 to 0.99831 , from $1.71303 \times 10^{-4}$ to 0.00132 and from 0.01309 to 0.03639 (white part).

Table 3. Drying time (h) of the yellow and white part of Gamboma's yam in the microwave.

\begin{tabular}{lcc}
\hline & Time $(\mathrm{h})$ & Powerful (W) \\
\hline Yellow part of the yam & 0.32 & 280 \\
White part of the yam & 0.1 & \\
\hline
\end{tabular}

Table 4. Modeling parameters for drying in an oven at $70^{\circ} \mathrm{C}$ and in a microwave at $280 \mathrm{~W}$.

\begin{tabular}{|c|c|c|c|c|c|c|c|c|}
\hline Sample & Model & $\mathrm{K}$ & A & B & $\mathbf{N}$ & $\mathbf{R}^{2}$ & $x^{2}$ & RMSE \\
\hline & Newton & 0.0054 & - & - & - & 0.98816 & 0.001 & 0.03167 \\
\hline $\begin{array}{l}\text { Dioscorea } \\
\text { cayenensis }\end{array}$ & Page & 0.00151 & - & - & 1.23369 & 0.99806 & $1.69642 \times 10^{-4}$ & 0.01302 \\
\hline \multirow{2}{*}{$\begin{array}{c}(\text { Yellow part) at } \\
70^{\circ} \mathrm{C}\end{array}$} & Henderson & 0.00569 & 1.05982 & - & - & 0.99112 & $7.77739 \times 10^{-4}$ & 0.02789 \\
\hline & Midilli & 0.0015 & 0.98788 & $-1.12208 \times 10^{-5}$ & 1.23007 & 0.99849 & $1.41281 \times 10^{-4}$ & 0.01189 \\
\hline \multirow{4}{*}{$\begin{array}{c}\text { Dioscorea } \\
\text { cayenensis } \\
\text { ( White Part) } \\
\text { at } 70^{\circ} \mathrm{C}\end{array}$} & Newton & 0.00568 & - & - & - & 0.98527 & 0.00132 & 0.03639 \\
\hline & Page & 0.00132 & - & - & 1.27093 & 0.99783 & $2.02264 \times 10^{-4}$ & 0.01422 \\
\hline & Henderson & 0.00617 & 1.0994 & - & - & 0.99336 & $5.4566 \times 10^{-4}$ & 0.0233 \\
\hline & Midilli & 0.00117 & 0.97988 & $-9.63489 \times 10^{-6}$ & 1.28698 & 0.99831 & $1.71303 \times 10^{-4}$ & 0.01309 \\
\hline \multirow{4}{*}{$\begin{array}{c}\text { Dioscorea } \\
\text { cayenensis } \\
\text { (Yellow part) } \\
\text { at } 280 \mathrm{~W}\end{array}$} & Newton & 0.1362 & - & - & - & 0.90815 & 0.01269 & 0.11264 \\
\hline & Page & 0.01677 & - & - & 1.99661 & 0.99943 & $8.38231 \times 10^{-5}$ & 0.00916 \\
\hline & Henderson & 0.15785 & 1.18096 & - & - & 0.9381 & 0.00903 & 0.095 \\
\hline & Midilli & 0.01551 & 0.98984 & $-1.64427 \times 10^{-4}$ & 2.02516 & 0.99954 & $7.47645 \times 10^{-5}$ & 0.00865 \\
\hline \multirow{4}{*}{$\begin{array}{c}\text { Dioscorea } \\
\text { cayenensis } \\
\text { (White Part) } \\
\text { at } 280 \mathrm{~W}\end{array}$} & Newton & 0.17793 & - & - & - & 0.95498 & 0.00473 & 0.06875 \\
\hline & Page & 0.07209 & - & - & 1.47762 & 0.99609 & $4.14481 \times 10^{-4}$ & 0.02036 \\
\hline & Henderson & 0.19547 & 1.11836 & - & - & 0.96124 & 0.0051 & 0.7142 \\
\hline & Midilli & 0.05486 & 0.98475 & -0.00149 & 1.58645 & 0.99666 & $5.07407 \times 10^{-4}$ & 0.02253 \\
\hline
\end{tabular}


For the two parts of Dioscorea cayenensis dried in the microwave, these values vary from 0.90815 to 0.99954 , from $7.47645 \times 10^{-5}$ to 0.01269 and from 0.11264 to 0.00865 (yellow part) and from 0.95498 to 0.99666 , from $4.14481 \times 10^{-4}$ to 0.0051 and from 0.02036 to 0.7142 (white part) respectively for $\mathrm{R}^{2}, \chi^{2}$ and RMSE. According to the models used, Midili's model gives the highest values of the coefficient of determination $\mathrm{R}^{2}$ and the lowest values of $\chi^{2}$ and RMSE.

Thus for the yellow part in the oven, these values are $0.99849,1.41281 \times 10^{-4}$ and 0.01189 and for the white part in the oven, they are $0.99831,1.71303 \times 10^{-4}$ and 0,01309 respectively for $\mathrm{R}^{2}, \chi^{2}$ and RMSE. For the yellow part in the microwave, these values are $0.99954,7.47645 \times 10^{-5}$ and 0.00865 and for the white part in the microwave, they are $0.99666,5.07407 \times 10^{-4}$ and 0,02253 respectively for $\mathrm{R}^{2}, \chi^{2}$ and RMSE.

According to the results obtained (case of oven and microwave drying), the Midilli model is considered to be the best to describe the drying behavior of $\mathrm{Di}$ oscorea cayenensis followed by the model of Page [18] [19].

Among the different models used, Midili's model showed the highest values for $\mathrm{R}^{2}$ and the lowest for $\chi^{2}$ and RMSE. Figure 3(a) and Figure 3(b) above illustrate the curves obtained with the Midili model.

The analysis of Figure 3(a) and Figure 3(b) shows that the drying is carried out in two distinct periods, which can be seen on the two almost linear parts of the curves. This indicates, according to Maskan [28], that drying takes place in two stages during the slowing down phase. Indeed, according to Nadeau and Puiggali [30] for hygroscopic materials (case of Gamboma yam), during the slowing down phase of drying, there are two periods. The first one starts at critical point 1 , where the evaporation zone "drying front" moves from the surface of the material towards the interior. The sudden reduction of the effective transfer area due to insufficient free water supply is the cause of this slowdown. The second period or "final pace period" is the transition to critical point 2 (unique to hygroscopic materials). The mass flow decreases more rapidly than the previous one, and only bound water remains in the material, which is evacuated slowly.

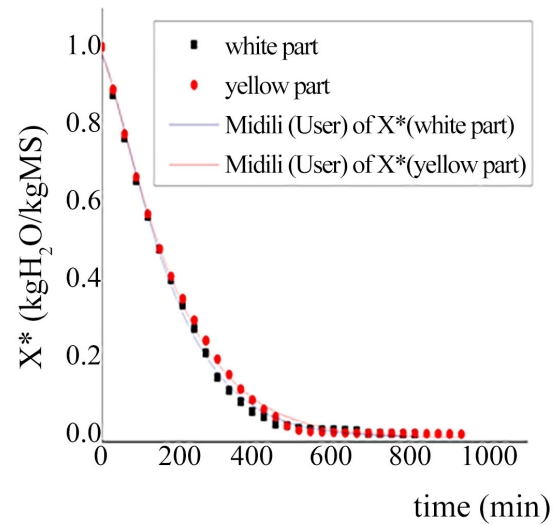

(a)

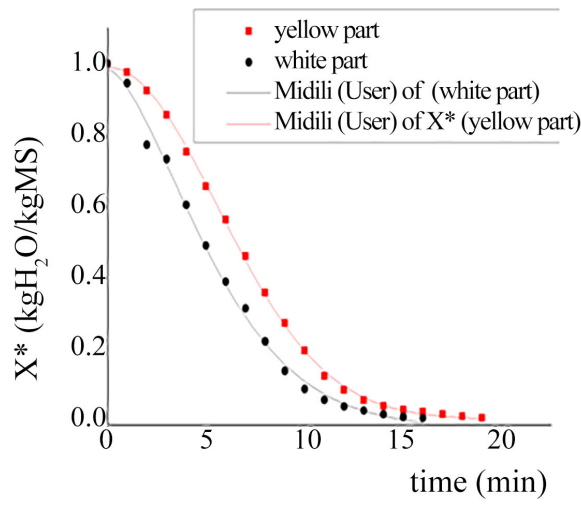

(b)

Figure 3. ( $a$ and $b$ ) Modeling of oven and microwave drying. 


\section{Conclusions}

In this work, the drying kinetics of two parts of the Gamboma yam (yellow and white) was studied. By examining the behaviour of these two parts, it was found that the two parts of the yam do not have the same drying behaviour. The results show that the yellow and white parts have respectively 800 and 950 minutes of drying time in the oven at $70^{\circ} \mathrm{C}$ against 16 to 19 minutes of drying time in the microwave at $280 \mathrm{~W}$.

The drying kinetics of the Gamboma yam pulp in the oven and microwave indicated a decrease in moisture content. Changes in moisture content levels during drying at $70^{\circ} \mathrm{C}$ and $280 \mathrm{~W}$ were plotted against time in the form of curves. With regard to the drying rate curves, the curves obtained note the presence of the product heating phase (phase 0), the constant rate drying phase (phase 1) and the sole presence of phase 2 . This phase is called the decreasing speed drying phase, during which the drop in water evaporation flow is due to the passage of the surface into the hygroscopic domain and is partially compensated by a rise in the temperature of the Gamboma yam pulp. The white part is the one that dries faster due to the faster rise in its core temperature, so it is the geometric shape of the yam that is most suitable for microwave drying. As for the oven, the drying kinetics is strongly influenced by the long drying time of up to 950 minutes.

The fit statistics of the different models were fitted to the expressions of the Newton, Page, Midili and Henderson and Pabis models. Of these models, the Midili model satisfactorily described the dehydration characteristics of both parts of the Gamboma yam pulp due to a better fit of its statistical parameters.

In perspective, this study will help us to optimize further work, particularly on the dehydration conditions of the species studied, by determining their drying kinetics using the most suitable means, i.e. the microwave and the oven at well-defined powers and temperatures.

\section{Conflicts of Interest}

The authors declare no conflicts of interest regarding the publication of this paper.

\section{References}

[1] Polycarp, D., Afoakwa, E.O., Budu, A.S. and Otoo, E. (2012) Characterization of Chemical Composition and Anti-Nutritional Factors in Seven Species within the Ghanaian Yam (Dioscorea) Germplasm. International Food Research Journal, 19, 985-992.

[2] Stessens, J. (2002) Analyse technique et économique des systèmes de production agricole au nord de la côte d'ivoire. Thèse de Doctorat No. 530 à la Faculté des Sciences Biologiques Appliquées de la KU Leuven, Katholieke Universiteit te Leuven, Leuven, $63 \mathrm{p}$.

[3] Ridene, H., Azzouz, S., Ghorbel, D., et al. (2006) Séchage des tomates par l'air chaud: Cinétique et qualité. 1er Séminaire Maghrébin sur les Sciences et Technologies de séchage. 
[4] Arlabosse, P. (2008) Séchage industriel: Aspects pratiques. Techniques de l'Ingénieur, J2455, 1-24.

[5] Vernier, P., N'kpenu, K.E. and Orkwor, G.C. (1999) Nouvelle demande en cossettes d'igames: Conséquences sur la production d'ignames en Afrique de l'Ouest. Agriculture et développement $\mathrm{n}^{\circ}$ 23-Septembre 1999, $32 \mathrm{p}$.

[6] Akissoé, N., Cornet, D. and Vernier, P. (2007) Effet du tranchage mécanique des cossettes d'igname sur la qualité finale. Atelier final du projet FAO TCP igname.

[7] Vernier, P., Hounhouigan, J. and Bricas, N. (2000) La transformation des ignames en cossettes et les préparations culinaires dérivées: Une technique de transformation qui renforce la sécurité alimentaire en réduisant les pertes après-récolte et qui contribue à augmenter le revenu des femmes rurales. GTZ, Eschborn, 28 p.

[8] Aboudou, R. and Auriole, L. (2006) Impacts de la croissance urbaine sur les filières agricoles en Afrique de l'Ouest: Cas de l'igname à Parakou, Bénin, Ifeas, Lares, document de travail Ecocité ${ }^{\circ} 13,51 \mathrm{p}$.

[9] Loko, Y.L., Dansi, A., Tamo, M., Bokonon-Ganta, A.H., Assogba, P., Dansi, M., Vodouhè, R., Akoegninou, A. and Sanni, A. (2013) Storage Insects on Yam Chips and Their Traditional Management in Northern Benin. The Scientific World Journal, 2013, Article ID: 484536. https://doi.org/10.1155/2013/484536

[10] Perumal, R. (2007) Comparative Performance of Solar Cabinet, Vacuum Assisted Solar and Open Sun Drying. Thesis of Master of Science, Department of Bioresource Engineering, McGill University, Montreal.

[11] Yilbas, B.S., Hussain, M.M. and Dincer, I. (2003) Heat and Moisture Diffusion in Slab Products to Convective Boundary Condition. Heat Mass Transfer, 39, 471-476. https://doi.org/10.1007/s00231-002-0323-x

[12] Bonazzi, C. and Bimbenet. J.J. (2002) Séchage des produits alimentaires. Principes. Techniques de l'Ingénieur, traité Agroalimentaire, Paris.

[13] AOAC (1990) Official Methodes of Analysis. 15th Edition, Association of Official Analytical Chemist, Washington DC.

[14] Aghbashlo, M., Kianmehr, M.H. and Samimi-Akhijahani, H. (2008) Influence of Drying Conditions on the Effective Moisture Diffusivity, Energy of Activation and Energy Consumption during the Thin-Layer Drying of Beriberi Fruit (Berberidaceae). Energy Conversion and Management, 49, 2865-2871. https://doi.org/10.1016/j.enconman.2008.03.009

[15] Doymaz, I. (2005) Drying Characteristics and Kinetics of Okra. Journal of Food Engineering, 69, 275-279. https://doi.org/10.1016/j.jfoodeng.2004.08.019

[16] Boughali, S., Benmoussa, H., Bouchekima, B., Mennouche, D., Bouguettaïa, H. and Bechki, D. (2009) Crop Drying by Indirect Active Hybrid Solar-Electrical Dryer in the Eastern Algerian Septentrional Sahara. Solar Energy, 83, 2223-2232. https://doi.org/10.1016/j.solener.2009.09.006

[17] Kavvadiasa, V., Doulaa, M.K., Komnitsasb, K. and Liakopouloua, N. (2010) Disposal of Olive Oil Mill Wastes in Evaporation Ponds: Effects on Soil Properties. Journal of Hazardous Materials, 182, 144-155. https://doi.org/10.1016/j.jhazmat.2010.06.007

[18] Doymaz, I. (2007) Air-Drying Characteristics of Tomatoes. Journal of Food Engineering, 78, 1291-1297. https://doi.org/10.1016/j.jfoodeng.2005.12.047

[19] Demir, V., Gunhan, T., Yagcioglu, A.K. and Degirmencioglu, A. (2004) Mathematical Modelling and the Determination of Some Quality Parameters of Air-Dried Bay Leaves. Biosystems Engineering, 88, 325-335. 
https://doi.org/10.1016/j.biosystemseng.2004.04.005

[20] Beye, N.F., Kane, C., Ayessou, N.C., Talla, C., Sene, A. and Diop, C.M. (2018) Influence of Variety and Maturity Level on Natural Convective Heat Drying of Four Onion Varieties Grown in Senegal. Food and Nutrition Sciences, 9, 997-1013. https://doi.org/10.4236/fns.2018.98073

[21] Honoré, O.K., Francois, Z. and Hélène, D. (2019) Effect of Farm Product Intrinsic Properties on Convective Drying: Case of Okra. American Journal of Plant Sciences, 10, 101-110. https://doi.org/10.4236/ajps.2019.101009

[22] Roselló, C., Simal S., SanJuan, N. and Mulet A. (1997) Nonisotropic Mass Transfer Model for Green Bean Drying. Journal of Agriculture and Food Chemistry, 45, 337-342. https://doi.org/10.1021/jf960534c

[23] Gupta, P., Ahmed, J., Shivhare, U.S. and Raghavan, G.S.V. (2002) Drying Characteristics of Red Chilli. Drying Technology, 20, 1975-1987. https://doi.org/10.1081/DRT-120015579

[24] Aghbashlo, M., Kianmehr, M.H., Arabhosseini, A. and Nazghelichi, T. (2011) Modelling the Carrot Thin-Layer Drying in a Semi-Industrial Continuous Band Dryer. Czech Journal of Food Sciences, 29, 528-538.

https://doi.org/10.17221/158/2010-CJFS

[25] Bauman, B. and Escher, F. (1995) Mass and Heat Transfer during Deep-Fat-Frying of Patato Slices-I. Rate of Drying and Oil Uptake. LWT-Food Science and Technology, 28, 395-403. https://doi.org/10.1016/0023-6438(95)90023-3

[26] Soysal, Y., Oztekin, S. and Eren, O. (2006) Microwave Drying of Parsley: Modelling, Kinetics, and Energy Aspects. Biosystems Engineering, 93, 403-413. https://doi.org/10.1016/j.biosystemseng.2006.01.017

[27] Wang, J. and Xi, Y.S. (2005) Drying Characteristics and Drying Quality of Carrot Using a Two-Stage Microwave Process. Journal of Food Engineering, 68, 505-511. https://doi.org/10.1016/j.jfoodeng.2004.06.027

[28] Gögüs, F. and Maskan, M. (2001) Drying of Olive Pomace by a Combined Microwave-Fan Assisted Convection oven. Food/ Nahrung, 45, 129-132. https://doi.org/10.1002/1521-3803(20010401)45:2<129::AID-FOOD129>3.0.CO;2-T

[29] Falade, K.O., Olurin, T.O. Ike. E.A. and Aworh O.C. (2007) Effect of Pretreatment and Temperature on Air-Drying of Dioscorea alata and Dioscorea rotundata Slices. Journal of Food Engineering, 80, 1002-1010. https://doi.org/10.1016/j.jfoodeng.2006.06.034

[30] Nadeau, J.P. and Puiggali, J.R. (1995) Séchage: Des procédés physiques aux procédés industriels. 1st Edition, Technique et Documentation-Lavoisier, Paris, 307 p. 